\title{
PELATIHAN DAN PENDAMPINGAN PENYUSUNAN PERANGKAT TES MATA PELAJARAN MATEMATIKA PADA KELAS TINGGI DI SDS AL HILAL TARAKAN DAN SDN 032 TARAKAN \\ Training and Mentoring to Development of Mathematics Test in High Class in SDS Al-Hilal Tarakan and SDN 032 Tarakan
}

\author{
A.Wilda Indra Nanna ${ }^{1 *}$, Enditiyas Pratiwi \\ Jurusan Pendidikan Guru Sekolah Dasar, Fakultas Keguruan dan Ilmu Penddidikan, Universitas Borneo \\ Tarakan, Jl. Amal Lama no. 1 Tarakan \\ * Penulis Korespodensi : wiradjab@gmail.com
}

\begin{abstract}
ABSTRAK
Peningkatan kualitas layanan pendidikan merupakan salah satu agenda prioritas pembangunan pendidikan nasional tahun 2015-2016 sebagaimana telah diamanatkan di dalam Peraturan Presiden Nomor 2 tahun 2015 Tentang Rencana Pembangunan Jangka Menengah Nasional 2015-2016. Disamping tersedianya kurikulum yang handal, salah satu aspek terpenting dalam upaya menjalin kualitas layanan pendidikan adalah menyediakan system penilaian yang komprehensif sesuai dengan standar nasional pendidikan yang telah ditetapkan. Memperhatikan permasalahan prioritas yang dihadapi mitra, pengusul menimbang perlu dilaksanakan kegiatan pelatihan dan pendampingan guru dalam penyusunan perangkat tes mata pelajaran Matematika pada kelas tinggi di SDS Al Hilal Tarakan dan SDN 032 Tarakan guna dapat melaksanakan tugasnya sehari-hari di kelas secara lebih professional sehingga pada akhirnya mutu pendidikan kita dapat lebih terjaga dan terus meningkat dalam bentuk Ipteks Bagi Masyarakat $\left(I_{b} M\right)$.
\end{abstract}

Kata Kunci: Perangkat Tes, Matematika,

\begin{abstract}
Improving the quality of education services is one of the national education development priority agendas of 2015-2016 as mandated in Presidential Regulation No. 2 of 2015 on the National Medium Term Development Plan 2015-2016. Besides the availability of a reliable curriculum, one of the most important aspects in the effort to establish the quality of education services is to provide a comprehensive assessment system in accordance with national standards of education that has been established. Taking into account the priority issues faced by the partners, the proposers consider the need for training and teacher assistance activities in the preparation of Mathematics subjects in higher school in SDS Al Hilal Tarakan and SDN 032 Tarakan to be able to carry out their daily tasks in the classroom in a more professional manner so that in the end The quality of our education can be more awake and continue to increase in the form of Science for Society.
\end{abstract}

Keywords: preparation test, mathematics

Peningkatan kualitas layanan pendidikan merupakan salah satu agenda prioritas pembangunan pendidikan nasional tahun 2015-2016 sebagaimana telah diamanatkan di dalam Peraturan Presiden Nomor 2 tahun 2015 Tentang Rencana Pembangunan Jangka Menengah Nasional 2015-2016. Disamping tersedianya kurikulum yang handal, salah satu aspek terpenting dalam upaya menjalin kualitas layanan pendidikan adalah menyediakan system penilaian yang komprehensif sesuai dengan standar nasional pendidikan yang telah ditetapkan.

Menilai pencapaian hasil belajar merupakan tugas pokok seorang guru sebagai konsekuensi logis dari pelaksanaan perencanaan pembelajaran yang telah disusun setiap awal semester. Penilaian ini dimaksudkan untuk mengambil keputusan 
tentang keberhasilan siswa dalam mencapai kompetensi yang telah ditetapkan. Untuk mengetahui apakah seorang siswa sudah berhasil mencapai kompetensi atau belum, diperlukan informasi hasil belajar. Informasi hasil belajar siswa yang tepat dapat diperoleh melalui alat ukur atau alat penliaian yang dapat menghasilkan hasil pengukuran yang valid dan reliable.

Pengabdian Kepada Masyarakat merupakan suatu media untuk menjembatani dunia pendidikan dengan masyarakat, dimana Perguruan Tinggi dihadapkan pada masalah bagaimana agar warga masyarakat mampu menghadapi tantangan lebih jauh ke depan di era globalisasi. SDS Al Hilal merupakan salah satu sekolah swasta yang terletak tidak jauh dari pusat kota Tarakan dan berada di daerah pesisir pantai. SDN 032 Tarakan merupakan salah satu sekolah negeri yang terletak jauh dari pusat Kota Tarakan dan juga berada di pesisir pantai.

Berdasarkan hasil observasi dan wawancara dengan Bapak M. Nasir. P, S.Pd selaku Kepala Sekolah Mitra Pertama diperoleh informasi salah satu yang menjadi misi SDS Al Hilal adalah "meningkatkan professional guru pengajar" namun pada kenyataan yang terjadi adalah baru sebagian kecil guru kelas di SDS Al Hilal yang pernah mengikuti kegiatan-kegiatan pelatihan terkait dengan peningkatan kompetensi guru baik yang dilaksanakan di tingkat Kota Tarakan, tingkat provinsi, maupun tingkat nasional. Selain itu, pihak sekolah belum pernah mengadakan kegiatan workshop ataupun kegiatan lainnya yang dapat meningkatkan pengetahuan, kinerja dan keterampilan guru karena terkendala dalam permasalahan biaya operasional. Perbaikan sarana dan prasarana sekolah masih menjadi prioritas utama dari pihak sekolah.

Berdasarkan hasil wawancara dengan Bapak Sirajuddin, S. Pd selaku Kepala Sekolah Mitra Kedua diperoleh informasi bahwa guru-guru di SDN 032
Tarakan sudah sering terlibat dalam kegiatan pelatihan dalam rangka meningkatkan kompetensi guru, akan tetapi belum ada guru yang berkesempatan mengikuti kegiatan pelatihan terkait dengan penyusunan perangkat tes dan selama ini guru-guru membuat soal masih bersumber dari buku paket atau LKS. Salah satu guru di SDN 032 Tarakan yaitu guru kelas VI juga menyampaikan bahwa kesulitan utama yang sering dihadapi adalah ketika harus menyusun soal Ujian Akhir Semester dengan cakupan materi yang luas salah satunya mata pelajaran Matematika, dimana guru terkendala dalam pembuatan soal pilihan ganda sehingga terkadang memilih menggunakan soal uraian karena gampang membuatnya. Arikunto (2009) menyatakan bahwa tes uraian atau esai kurang representative dalam hal mewakili seluruh scope bahan pelajaran yang akan dites karena soalnya hanya beberapa saja (terbatas). Tes Objektif salah satunya pilihan ganda mengandung lebih banyak segi-segi yang positif, misalnya lebih representative mewakili isi dan luas bahan pelajaran.

Memperhatikan beberapa fakta yang telah diuraikan di atas, yang merupakan sebagian kecil dari permasalahanpermasalahan yang terjadi di bidang pendidikan, maka pengusul bersama dengan Kepala Sekolah SDS AL- Hilal Tarakan dan SDN 032 Tarakan menimbang perlu untuk memprioritaskan permasalahan nyata yang dihadapi oleh guru-guru, diantaranya:

1. Belum ada guru SDS Al-Hilal maupun SDN 032 Tarakan yang mengikuti kegiatan pelatihan penyusunan perangkat tes sehingga masih minim pengetahuan dan keterampilan dalam merakit soal ujian.

2. Guru kesulitan dalam membuat soal sendiri sehingga terbiasa mengambil soal bersumber dari buku paket/pegangan dan LKS tanpa memperhatikan kompetensi yang ingin dicapai peserta didik. 
3. Guru terbiasa membuat soal pada saat akan ujian tanpa kisi-kisi tes. Kisi-kisi tes hanya dibuat ketika ada supervisi di sekolah.

pelatihan dan pendampingan guru guna dapat melaksanakan tugasnya sehari-hari di kelas secara lebih professional sehingga pada akhirnya mutu pendidikan kita dapat lebih terjaga dan terus meningkat dalam bentuk Ipteks Bagi Masyarakat $\left(\mathrm{I}_{\mathrm{b}} \mathrm{M}\right)$ dalam kegiatan:

1. Pelatihan penyusunan perangkat tes yang baik.
Memperhatikan permasalahan yang dihadapi mitra maka perlu diadakan

2. Pendampingan dalam merakit perangkat tes mata pelajaran Matematika yang bisa digunakan dalam Ujian Akhir Semester (UAS) untuk kelas tinggi.

\section{METODE}

Beberapa permasalahan prioritas, mitra dan solusinya disajikan pada Tabel 1 .

Tabel 1. Permasalahan dan Solusi Pemecahan Masalah pada Mitra

\begin{tabular}{|l|l|l|l|}
\hline \multicolumn{1}{|c|}{ No } & \multicolumn{1}{|c|}{ Permasalahan Prioritas } & \multicolumn{1}{|c|}{$\begin{array}{c}\text { Mitra yang } \\
\text { Mengalami }\end{array}$} & \multicolumn{1}{c|}{$\begin{array}{c}\text { Metode } \\
\text { Pelaksanaan/Penyelesaian }\end{array}$} \\
\hline 1. & $\begin{array}{l}\text { Belum ada guru SDS Al-Hilal maupun } \\
\text { SDN 032 Tarakan yang mengikuti } \\
\text { kegiatan pelatihan penyusunan } \\
\text { perangkat tes sehingga masih minim } \\
\text { pengetahuan dan keterampilan dalam } \\
\text { merakit soal ujian }\end{array}$ & $\begin{array}{l}\text { Guru SDS Al } \\
\text { Hilal Tarakan dan } \\
\text { Guru SDN 032 } \\
\text { Tarakan }\end{array}$ & Pelatihan \\
\hline 2. & $\begin{array}{l}\text { Guru kesulitan dalam membuat soal } \\
\text { sendiri sehingga terbiasa mengambil } \\
\text { soal bersumber dari buku } \\
\text { paket/pegangan dan LKS tanpa } \\
\text { memperhatikan kompetensi yang ingin } \\
\text { dicapai peserta didik. }\end{array}$ & $\begin{array}{l}\text { Guru Kelas } \\
\text { Tinggi SDS Al } \\
\text { Hilal Tarakan dan } \\
\text { Guru SDN 032 } \\
\text { Tarakan }\end{array}$ & Pendampingan \\
\hline 3. & $\begin{array}{l}\text { Guru terbiasa membuat soal pada saat } \\
\text { akan ujian tanpa kisi-kisi tes. Kisi-kisi } \\
\text { tes hanya dibuat ketika ada supervisi di } \\
\text { sekolah. }\end{array}$ & $\begin{array}{l}\text { Guru SDS Al } \\
\text { Hilal Tarakan }\end{array}$ & $\begin{array}{l}\text { Pelatihan dan } \\
\text { pendampingan }\end{array}$ \\
\hline
\end{tabular}

Kegiatan ini rencana akan diadakan selama 3 bulan, tempat pelaksanaanya di SDS Al Hilal Tarakan dan SDN 32 Tarakan. Adapun metode yang akan digunakan adalah sebagai berikut:

Metode Pendekatan dan Pelaksanaan dimulai dengan penyesuaian paradigma para guru-guru SD maka perlu melakukan langkah-langkah berikut ini:

1. Sebelum tim peneliti berangkat ke lokasi mitra, pengusul menghubungi Kepala Sekolah SDS Al Hilal Tarakan dan SDN 32 Tarakan untuk

2. meminta kesiapan masing-masing guru sebagai peserta dalam kegiatan pelatihan dan pendampingan berdasarkan jadwal yang telah disusun peneliti.

3. Tim peneliti mempersiapkan materi pelatihan .

4. Tim peneliti melakukan pelatihan

penyusunan perangkat tes di SDS Al Hilal Tarakan dan SDN 32 Tarakan

5. Tim peneliti melakukan pendampingan dalam menyusun dan merakit soal Ujian Akhir Semester (UAS) mata pelajaran Matematika kelas tinggi di SDS Al Hilal Tarakan dan SDN 32 Tarakan.

Evaluasi pelaksanaan pelatihan dan pendampingan penyusunan perangkat tes 
mata pelajaran Matematika di SDS Al Hilal Tarakan dan SDN 032 Tarakan dilakukan melalui monitoring kegiatan. Monitoring merupakan pengumpulan data yang dimaksudkan apakah pelaksanaan kegiatan sesuai dengan rencana dan target luaran program pengabdian kepada masyarakat (IbM) melalui pelatihan dan pendampingan guru-guru di sekolah mitra. Melalui monitoring secara terencana dan bertahap program dapat diketahui apakah berjalan dengan baik. Informasi tersebut dapat dijadikan umpan balik bagi proses perencanaan dan pelaksanaan penyelenggaraan $\mathrm{IbM}$ ini. Dengan demikian, jika terjadi penyimpangan dapat dengan segera diketahui dan diperbaiki. Untuk itu, prinsip-prinsip monitoring harus terencana, terukur, kontinyu, komprehensip, dan objektif, sehingga keberhasilan kegiatan pelatihan dan pendampingan penyusunan perangkat tes mata pelajaran Matematika di kelas tinggi dapat diketahui.

\section{HASIL DAN PEMBAHASAN}

Pelaksanaan pengabdian pada masyarakat (IbM) ini dilakukan dalam beberapa tahapan. Tahap pertama dimulai dengan melakukan komunikasi dengan pihak mitra terkait yaitu Kepala Sekolah SDN 032 Tarakan dan Kepala Sekolah SDS Al-Hilal Tarakan dalam rangka mendata jumlah guru-guru yang akan mengikuti kegiatan pelatihan dan pendampingan penyusunan perangkat tes mata pelajaran Matematika. Pelaksanaan kegiatan pelatihan dan pendampingan penyusunan perangkat tes selama 3 (tiga) hari kerja terhitung dari tanggal $14-16$ November 2016

Data awal jumlah peserta pelatihan dan pendampingan di SDS Al Hilal Tarakan adalah sebanyak 10 orang peserta (Guru dan Kepala Sekolah) serta di SDN 032 Tarakan sebanyak 16 orang peserta (Guru, Kepala Sekolah dan guru utusan dari gugus). Pada saat pelaksanaan jumlah peserta yang hadir tidak sesuai dengan data awal. Pada SDS Al-Hilal Tarakan sebanyak 8 orang peserta yang hadir dan pada SDN 032 Tarakan sebanyak 10 orang peserta yang hadir. Dengan demikian jumlah peserta keseluruhan yang mengikuti kegiatan pelatihan dan pendampingan penyusunan perangkat tes mata pelajaran matematika pada kelas tinggi di SDS Al Hilal Tarakan dan SDN 032 Tarakan sebanyak 18 orang peserta.

Tahap awal sebelum pelaksanaan pengabdian pada masyarakat ini adalah tim peneliti melakukan persiapan berupa penyusunan materi pelatihan dan pendampingan yang akan disosialisasikan kepada kedua kelompok mitra yang telah dipilih. Materi yang disusun dan disiapkan yaitu teknik penulisan soal (Pilihan ganda, uraian dan isian), kaidah telaah soal (pilihan ganda, uraian dan isian), standar kompetensi dan kompetensi dasar mata pelajaran Matematika kelas IV-VI, kartu soal.

Hari pertama pengabdian dilaksanakan di sekolah mitra kedua yaitu SDS Al-Hilal Tarakan pada hari Senin 14 November 2016. Tim peneliti menjelaskan kepada peseta pelatihan dan pendampingan penyusunan perangkat tes mengenai bagaimana teknik yang dilakukan ketika akan menyusun sebuah soal baik dalam bentuk pilihan ganda, iian maupun uraian. Informasi awal yang diterima peneliti dari peserta adalah dalam melaksanakan UAS mata pelajaran matematika jumlah soal yang diujiankan berbeda di setiap kelas. Untuk kelas IV terdiri dari 25 soal pilihan ganda, 10 soal isian dan 5 soal uraian. Untuk kelas V terdiri dari 30 soal pilihan ganda, 10 soal isian dan 5 soal uraian. Sedangkan untuk kelas VI hanya terdiri dari 50 soal pilihan ganda.

Selama ini guru-guru di SDS AlHilal Tarakan membuat soal berdasarkan dari pertemuan yang dilakukan dalam kelompok gugus. Berdasarkan penyampaian materi mengenai telaah penulisan soal diperoleh informasi dalam 
menilai hasil tes UAS siswa mereka tidak mengalami kesulitan untuk soal pilihan ganda dan isian. Akan tetapi ketika soal uraian, ternyata guru belum memahami dengan jelas bagaimana membuat pedoman penskoran. Guru masih kesulitan ketika membuat rubric penskoran dan belum memahmi bahwa dalam rubric penkoran setiap kata kunci untuk soal uraian diberikan skor 1 . Selain itu ternyata guru juga masih bingung membedakan antara skor, bobot dan nilai siswa. Sehingga dengan adanya kegiatan pelatihan dan pendampingan ini guru merasa sangat terbantu dan mendapatkan pengetahuan dan ketrampilan baru mengenai bagaimana penilaian yang dilakukan untuk soal yang berbentuk uraian.

Pada kegiatan pendampingan penyusunan soal, peserta dibagi ke dalam tiga kelompok kecil yaitu kelompok pembuat perangkat tes mata pelajaran matematika untuk kelas IV sebanyak 2 orang guru, kelompok pembuat perangkat tes mata pelajaran matematika untuk kelas V sebanyak 2 orang guru dan kelompok pembuat perangkat tes mata pelajaran matematika untuk kelas VI sebanyak 3 orang guru. Kepala sekolah ikut membantu peneliti dalam melakukan pendampingan. Masing-masing peserta menyusun perangkat tes berdasarkan Standar Kompetensi dan kompetensi dasar semester ganjil dengan terlebih dahulu menyusun/membuat indikator. Perangkat tes yang dibuat dalam kartu soal yaitu soal berbentuk pilihan ganda dan soal berbentuk uraian.

Hari kedua pengabdian dilaksanakan di sekolah mitra pertama yaitu SDN 032 Tarakan pada hari Selasa 15 November 2016. Tim peneliti menjelaskan kepada peseta pelatihan dan pendampingan penyusunan perangkat tes mengenai bagaimana teknik yang dilakukan ketika akan menyusun sebuah soal baik dalam bentuk pilihan ganda, isian maupun uraian. Informasi awal yang diterima peneliti dari peserta adalah dalam melaksanakan UAS mata pelajaran matematika jumlah soal yang diujiankan berbeda di setiap kelas. Untuk kelas IV terdiri dari 25 soal pilihan ganda, 10 soal isian dan 5 soal uraian. Untuk kelas $\mathrm{V}$ terdiri dari 30 soal pilihan ganda, 10 soal isian dan 5 soal uraian. Sedangkan untuk kelas VI hanya terdiri dari 50 soal pilihan ganda.

Guru-guru di SDN 032 Tarakan sebagai peserta kegiatan pelatihan dan pendampingan ini hanya mengetahui mengenai teknik dan kaidah penulisan soal dari kelompok gugus dan tidak semua guru pernah mendapatkan materi bagaimana menyusun dan menelaah soal. Sehingga pada saat penyampaian materi pelatihan, banyak peserta yang angat antusias bertanya bagaimana dan seperti apa yang harus dilakukan ketika memberikan penilaian kepada hasil belajar siswa.

Setelah materi teknik penulisan soal dan kaidah telaah soal selesai disampaikan kemudian dilanjutkan dengan kegiatan pendampingan penulisan soal matematika. Peserta juga dibagi ke dalam tiga kelompok yaitu kelompok penyusul soal kelas IV, kelompok penyusun soal kelas V, dan kelompok penyusun soal kelas VI. Setiap pesrta dibagikan standar kompetensi dan kompetensi dasar mata pelajaran matematika yang akan digunakan oleh mereka sebagai pedoman dalam menyusun kisi-kisi soal sehingga memudahkan mereka ketika menulis soal dalam kartu soal yang dibagikan.

Selama kegiatan pendampingan penyusunan soal berlangsung, peserta bekerja dengan antusias untuk mengisi kartu soal yang telah dibagikan. Tim peneliti juga katif memberikan penjelasan dan pengarahan kepada peserta ketika ada yang kesulitan dalam menyusun soal.

Hari ketiga pengabdian ini berupa review kartu soal yang telah disusun oleh semua peserta. Tim peneliti melakukan review sebagai umpan balik terhadapa soalsoal yang telah disusun oleh peserta. 
Review yang dilakukan oleh tim peneliti meliputi telaah kaidah materi, konstukrsi, bahasa dan tata tulis. Hasil review disampaikan kepada peserta ehingga mereka paham dan mengetahui sejauh mana kemampuan mereka dalam menyusun/ menulis soal yang baik sesuai dengan kaidah yang ada. Berdasarkan hasil review yang dilakukan rata-rata peserta masih kesulitan ketika menyusun soal pilihan ganda yaitu ketika membuat rumusan pokok soal dan membuat pilihan jawaban yang homgen. Sehingga berdasarkan hasil review, tim peneliti memberikan trik-trik bagaimana cara menyusun pilihan jawaban yang homogen.

Berdasarkan dari rangkaian kegiatan pelatihan dan pendampingan penyusunan perangkat tes mata pelajaran Matematika dapat disimpulkan bahwa output atau target luaran yang diharapkan dalam kegiatan pengabdia pada masyarakat ini telah tercapai. Guru-guru sebagai sasaran dari kegiatan ini telah menunjukkan peningkatan keterampilan pemahaman bagaimana merakit soal yang baik sesuai dengan penulisan soal baik dalam bentuk pilihan ganda, isian dan uraian. Dengan melihat hasil tersebut, diharapkan guruguru kedepannya sudah terbiasa bahkan mahir menyusun soal-soal khususnya untuk mata pelajaran matematika tanpa bantuan buku paket/ mengambil langsung dari LKS/buku paket.

Dari kegiatan pelatihan dan pendampingan pendampingan penyusunan perangkat tes mata pelajaran Matematika ini, tim peneliti dan peserta berhasil menyususn perangkat tes mata pelajaran Maematika dalam bnetuk produk yang sudah bisa langsung digunakan pada sekolah masing-masing di kelas IV, V dan VI.

\section{PENUTUP}

Berdasarkan rangkaian kegaiatn yang dilaksanakan, tim peneliti menyimpulkan bahwa kegiatan pengabdian pada masyarakat ini dalam bentuk pelatihan dan pendampingan penyusunan perangkat tes UAS mata pelajaran matematika pada kelas tinggi di SDN 032 Tarakan dan SDS Al-Hilal Tarakan sebagai berikut:

1. Sasaran dari program pengabdian pada masyarakat tercapai

2. Adanya peningkatan keterampilan pemahaman guru-guru bagaimana merakit soal yang baik sesuai dengan penulisan soal baik dalam bentuk pilihan ganda, isian dan uraian.

3. Guru memperoleh informasi dan tambahan pengalaman dalam merakit perangkat tes khususnya untuk mata pelajaran Matematika

4. Tersedianya produk yang dihasilkan dari kegiatan ini berupa perangkat tes UAS mata pelajaran matematika untuk Kelas IV, V, dan VI.

\section{DAFTAR RUJUKAN}

Arikunto, S. (2009) Dasar-Dasar Evaluasi Pendidikan. Bandung: Alfabeta

Peraturan Presiden Republik Indonesia. (2015). Perpres Republik Indonesia Tentang Rencana Pembangunan Jangka Menengah Nasional Tahun 2015-2019 